Akademik Siyer Dergisi / Journal of Academic Sirah

e-ISSN: $2687-5810$

Y1l / Year: 3, Say1 / Issue: 5, Sayfa / Page: 13-28

\title{
Kırmızı Kıyafet Giymenin Hükmü ile İlgili Rivâyetlerin Coğrafî Tahlîli
}

Geographic Analysis of Hadiths Regarding Prohibition of Wearing Red

\section{Hüseyin Akgün}

Prof. Dr., Ondokuz Mayıs Üniversitesi İlahiyat Fakültesi, Hadis Ana Bilim Dalı

Prof. Dr., Ondokuz Mayss University Faculty of Teology, Department of Hadith Samsun / Turkey

huseyinakgun@hotmail.com

orcid.org/ 0000-0002-5335-9901

\section{Makale Bilgisi / Article Information}

Makale Türü: Araştırma Makalesi / Article Type: Research Article

Geliş Tarihi: 10 Temmuz 2021 / Date Received: 10 July 2021

Kabul Tarihi: 8 Eylül 2021 / Date Accepted: 8 September 2021

Yayın Tarihi: 1 Ocak 2022 / Date Published: 1 January 2022

Yayın Sezonu: Ocak 2022 / Pub Date Season: January 2022

Atıf: Akgün, Hüseyin. "Kırmızı Kıyafet Giymenin Hükmü ile İlgili Rivâyetlerin Coğrafî Tahlîli”. Akademik Siyer Dergisi 5 (Ocak 2022), 13-28.

Citiation: Akgün, Hüseyin. “Geographic Analysis of Hadiths Regarding Prohibition of Wearing

Red". Journal of Academic Sirah 5 (January 2022), 13-28.

https://doi.org/ 10.47169/samer.969599

Intihal: Bu makale, iTenticate yazılımınca taranmıştır. İntihal tespit edilmemiştir.

Plagiarism: This article has been scanned by iTenticate. No plagiarism detected.

web: http://dergipark.gov.tr/samer e-mail: akademiksiyerdergisi@ksu.edu.tr

Copyright (C) Published by KSÜ Siyer-i Nebi Araştırmaları Uygulama ve Araştırma Merkezi

KSU Sirah Researches Application and Research Center

Kahramanmaraş 46100 Turkey

Bütün hakları saklıdır. / All right reserved. 


\title{
Öz
}

Renklerin görsel/sanatsal güzelliğinin yanı sıra toplumlar için farklı sembolik anlamları da söz konusudur. Bu sembol renklerden biri 'cehennemin rengi', 'şeytanın rengi', 'isyanın rengi' gibi çeşitli anlamlar yüklenen kırmızıdır. Bu bağlamda İslam kaynaklarında kırmızı kıyafet giymeyi hem yasaklayan hem de buna izin veren rivâyetler dikkat çekmektedir. Araştırmamızda ilgili rivâyetler arasındaki bu ihtilafı anlamak için bunları coğrafî olarak tahlil etmenin ve bir değerlendirme yapmanın uygun olacağı düşünülmüştür. Çalışmadaki amacımız ister dinî olsun ister siyasî, bir bölge halkının herhangi bir konudaki tutumunun rivâyetlerin menşeine yansıdığını göstermek, rivâyet-coğrafya ilişkisine dikkat çekmektir. Hadislerin rivâyet edildiği coğrafyanın göz önünde bulundurularak değerlendirilmesi bunların sıhhatinin tespiti, mevzû olanların siyasî ve sosyo-kültürel arka planlarının belirlenmesi, bir konudaki hadis metinlerinin yeniden inşası gibi konularda yardımcı olabilmektedir. Bu bağlamda ele aldığımız hadisleri "kırmızı giymeyi yasaklayan rivâyetler" ve "kırmızı giymeyi mubah gösteren rivâyetler" başlıkları altında değerlendirilmiş ve bu yasaklamanın muhtemel sebepleri üzerinde durulmaya çalışılmıştır.

Anahtar Kelime: Hadis, Kırmızı kıyafet, Coğrafî tahlil, Irak, Şam.

\begin{abstract}
As an addition to the visual/artistic beauty of colors, they also have different symbolic meanings for societies. One of those colors that is ascribed several meanings such as "color of hell", "color of devil", "color of rebellion" is red. In this regard, hadiths which both prohibit and allow to wear red draw attention in Islamic sources. We, in this study, thought that it would be to the point to geographically analyze and make an evaluation to understand the dispute among relevant hadiths. The purpose of this study was to show that the attitude of a community, regardless of being religious or political, reflects the origin of hadiths on any issue. To be pointed out the relationship between hadiths and geography was also the purpose. Evaluation of the hadiths by taking into consideration the geography where they were narrated can help to understand the issues such as determining their accuracy, the political and socio-cultural backgrounds of them, and also reconstruction of hadith texts on a subject. Accordingly, we evaluated the hadiths under two titles as "the hadiths that prohibit to wear red" and "the hadiths that allow wearing red". Then, possible reasons for this prohibition were dwelled on.
\end{abstract}

Keywords: Hadith, Red clothes, Geographical analysis, Iraq, Syria. 
15 Hüseyin Akgün / Kırmızı Kıyafet Giymenin Hükmü ile İlgili Rivâyetlerin Coğrafî Tahlîli / Geographic Analysis of Hadiths Regarding Prohibition of Wearing Red

\section{GİRIŞ}

Renklerin görsel/sanatsal güzelliğinin yanı sıra toplumlar için değişik sembol anlamları da olmuştur. Bu sembol renklerden biri, cehennemin/şeytanın/isyanın rengi gibi değişik anlamlar yüklenen kırmızıdır. Bu bağlamda hadis kaynaklarında özellikle kırmızı kıyafet giymenin Hz. Peygamber, sonrasında bazı sahâbe ve tâbiîn tarafından yasaklandığı veya hoş karşılanmadığı yönünde rivâyetler bulunmaktadır. ${ }^{1}$ Buna karşılık bu rengi giymenin mubahlığını savunan hadisler de nakledilmektedir. Biz bu konudaki rivâyetlerin bölgesel/coğrafî bir temelinin olup olmadığını araştırmak ve bu yasaklamanın muhtemel nedenleri ve sembol anlamı üzerinde durmak istedik. Aşağıda sırasıyla önce kırmızı giymeyi yasaklayan, daha sonra ise mubah olduğunu savunan rivâyet ve görüşlere yer vererek araştırmamızda bir sonuca ulaşmaya çalışacağız.

\section{KIRMIZI GIYMEYI YASAKLAYAN RIVÂYETLER VE BU YÖNDEKI GÖRÜŞLER}

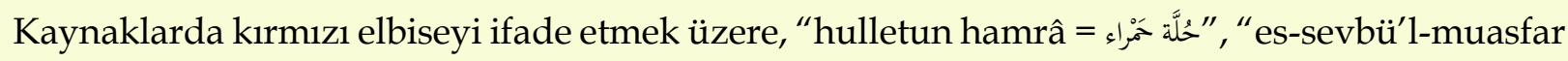

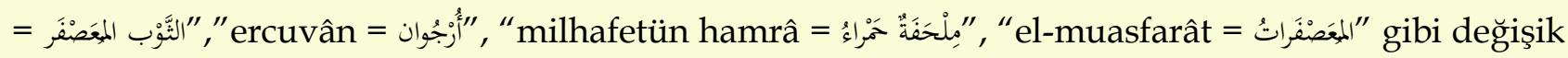
ifadeler kullanılmaktadır. Hadis, tefsir ve fıkıh kitaplarında kırmızı kıyafet giymeyle ilgili Hz. Peygamber' den gelen rivâyetlerin yanı sıra mevkûf ve maktu' bazı rivâyetlere de yer verilmektedir. Bu rivâyetlerin büyük bir kısmı kırmızı kıyafet giymeyi yasaklamaktadır. Şimdi bunları tarihi sirasıyla ele alacağız.

Bu yasaklama konusunda tespit edebildiğimiz en eski rivâyet, Medineli İbrahim b. Abdullah b. Huneyn'in (ö. 100/718'den sonra) babasından, onun da Hz. Ali'den naklettiği şu hadistir:

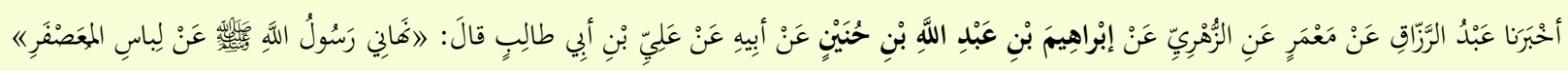

... Ali b. Ebî Tâlib (ö. 40/661): "Rasûlullah (s.a.s.) bana kırmız² kıyafet giymeyi yasakladı."3

Aşağıda yine İbrahim' den gelen başka bir tarikte, farklı bir lafızla nakledilmiş olup Hz. Ali'nin bunu Kûfe meydanında söylediğinin vurgulanmış olması dikkat çekmektedir.

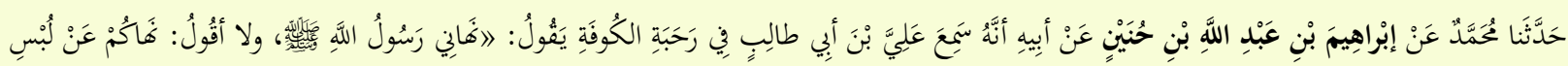

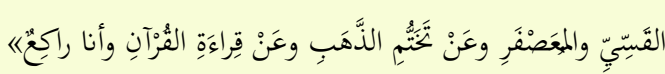

1 Renkler ile ilgili daha önce yapılan bazı çalışmalar için bk. Bk. Soner Gündüzöz, “Kur'ân'da Renklerin Büyülü Gücü -Semiotik Bir İnceleme-", EKEV Akademi Dergisi - Sosyal Bilimler -, 7/16 (2003), 71-84; Hüseyin Akyüz, "Hz. Peygamber'in Hadislerinde Renklerin Dili", Atatürk Üniversitesi İlahiyat Fakültesi Dergisi, 41 (2014), 373397.

2 Muasfar: Yalancı safran (usfur) ile boyanmış şey. Bu bitkiden (türüne göre) kırmızı veya sarı renkleri elde edilebiliyor olsa da hadis kitapları ve lügatlerdeki 'kırmızıya boyanmış" anlamından hareketle en azından söz konusu dönemlerde bu bitkiden kırmızı boya elde edildiğini söyleyebiliriz. Hadis kitaplarındaki misal için

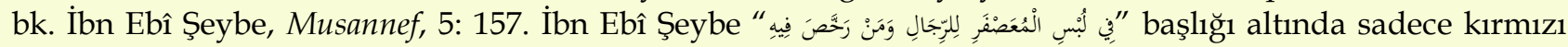
giyme ile ilgili hadisleri nakletmektedir. Lügatler için bk. Halîl b. Ahmed, el-Ayn, 5: 160. Özellikle bk. İbn Sîde, Muhassas, 3: 273-274; Zebîdî, Tâcu'l-arûs, 7: 236. Dolayısıyla buna 'sarıya boyanmış' şeklinde mana vermek isabetli değildir.

${ }^{3}$ Ma'mer, Câmi', 11: 77 (No. 19964). 
... Ali b. Ebî Tâlib Kûfe meydanında şöyle bir hitapta bulunmuştur: "Rasûlullah (s.a.s.) bana size değil- ipekli elbise ve kırmızı giymeyi, ayrıca altın yüzük takmayı ve rükûdayken Kur'ân okumayı yasaklad1." 4

Mâlik' in yine aynı râvi aracılığıyla naklettiği diğer bir tarikte (Yahyâ b. Yahyâ rivâyetinde) de bu 'muasfar' kısmı bulunmamakla5 birlikte diğer bazı rivâyetlerinde bu ifade bulunmaktadır.

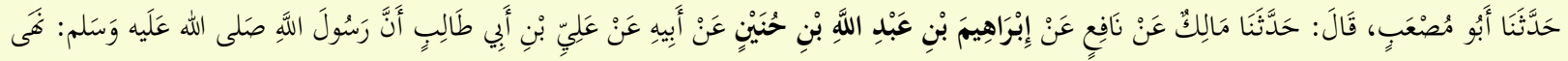

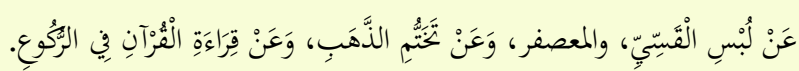

... Ali b. Ebî Tâlib, Rasûlullah'ın ipekli elbise ve kırmızı giymeyi, altın yüzük takmayı, ayrıca rükûdayken Kur'ân okumayı yasakladığını haber verdi. ${ }^{6}$

Yukarıdaki bütün bu farklı rivâyetlerin Medineli İbrahim b. Abdullah'a nispet edilmiş olması ve onun bu rivâyetlerin medârı (ortak râvisi) olması dikkat çekmektedir.

Daha da ilginç olan Kûfelilerin Hz. Ali' den diğer bir rivâyetlerinde bu kırmızı elbise kısmının bulunmaması, onun yerine kirmızı eyer anlamina gelen " الميثرَة الحمَراء = kirmız1 eyer/semer" k1sminın yer almasidir:

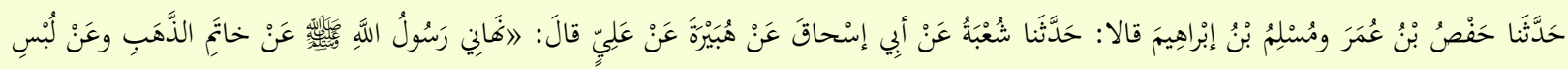

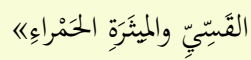

... Ali b. Ebî Tâlib: "Rasûlullah bana altın yüzük takmayı, ipekli elbise giymeyi ve kırmızı eyere binmeyi yasakladı."7

Hasan-1 Basrî́ye (ö. 110/728) isnâd edilen bir rivâyet, ondan mürsel olarak şu şekilde gelmektedir:

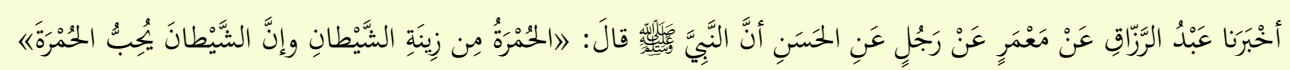

... Hasan-1 Basrî: Hz. Peygamber buyurdu ki: “Kırmızı, şeytanın ziynetindendir ve muhakkak şeytan kırmızıyı sever."8

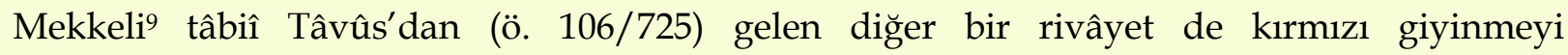
kötülemektedir:

4 Ali b. Hucr, Hadîsu Alî b. Hucr, 1: 302 (No. 226). Burada râvilerden birinin açıklaması Hz. Ali'ye atfedilmiş gibi görünmektedir.

5 Mâlik, "Salât", 28.

${ }^{6}$ Mâlik b. Enes, el-Muvatta': rivâyetü Ebî Mus'ab ez-Zührî el-Merînî, 1: 86 (No. 224). Bu hadisin sened ve metnindeki ihtilaflar hususunda ayrıca bk. Dârekutnî, İlel, 3: 78-88.

7 Ebû Dâvûd, "Libâs", 11 (No. 4051). Şuayb el-Arnaût bu hadisin sahih olduğuna hükmetmektedir. Kûfelilerin diğer bir rivâyeti için bk. Ahmed, Müsned, 2: 270 (No. 963). Bu rivâyet Kûfelilerin Hz. Ali rivâyetinden haberdar olduklarını ancak yasaklanan şeyin zabtı konusunda Medinelilerden ayrıldıklarını göstermektedir.

8 İbnü'l-Kayserânî, Ma'mer'in "raculun" olarak meçhul bıraktığ1 ismi "Selmâ b. Abdullah el-Hüzelî" olarak vermekte ve onun metrûku'l-hadîs olduğunu belirtmektedir (İbnü'l-Kayserânî, Zehîratü'l-huffâz, 1: 560). İbü'lCevzî (ö. 597/1201) de bu hadis hakkında bâtıl hükmünü vermektedir (İbnü'l-Cevzî, el-Ebâtil, 3: 300-301).

9 Tâvûs her ne kadar aslen Yemenli olsa da onun ilminin kaynağı daha çok Mekke'dir. Nitekim o, Mekke tefsir ekolünün önde gelen âlimlerinden kabul edilmektedir (Bk. Abdullah Kahraman, "Tâvûs b. Keysân", 40: 185). 
17 Hüseyin Akgün / Kırmızı Kıyafet Giymenin Hükmü ile İlgili Rivâyetlerin Coğrafî Tahlîli / Geographic Analysis of Hadiths Regarding Prohibition of Wearing Red

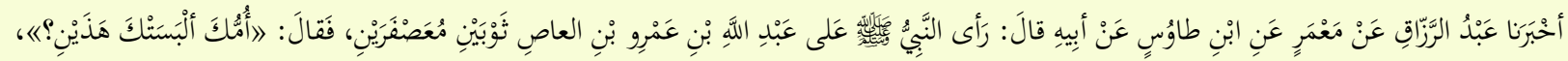

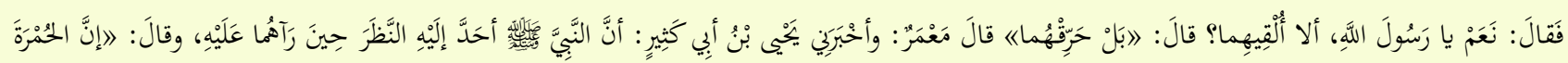

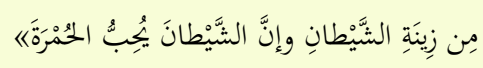

Tâvûs: “Nebî (s.a.s.) Abdullah b. Amr üzerinde iki parça kırmızı elbise gördü ve şöyle dedi: ‘Bunu sana annen mi giydirdi?'. O da cevaben ‘Evet, onları atayım mı?' dedi. Hz. Peygamber de “Bilakis onları yak!" şeklinde cevap verdi."10 Ma'mer (ö. 153/770) bu hadisin devaminda Yahyâ b. Ebî Kesîr'den (ö. 129/747) yukarıdaki Hasan-1 Basrî hadisinin aynı lafzıyla, bu hadisin farklı bir varyantı olarak nakletmektedir. Şöyle ki, burada Hz. Peygamber'in onun üzerindeki bu iki parça kırmızı elbiseyi görünce ona dikkatle bakarak şunları söylediği nakledilmektedir: "Kırmızı, şeytanın ziynetidir ve muhakkak şeytan kırmızıyı sever."11

Yukarıdaki hadis, Tâvûs dışında bu sefer farklı bir lafızla ve doğrudan Abdullah b. Amr'a (ö. 65/685) isnâd edilerek Humuslulardan (Şam) da nakledilmektedir:

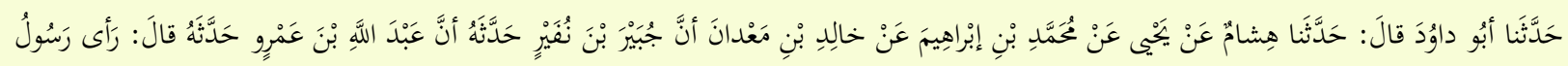

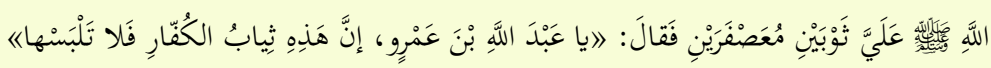

Cübeyr b. Nüfeyr (ö. 80/699), Abdullah b. Amr'ın ona şunları söylediğini haber vermektedir: “Rasûlullah benim üzerimde iki parça kırmızı elbise gördü ve şöyle dedi: 'Ey Abdullah b. Amr! Bu kâfirlerin kıyafetidir. Onu giyme!'”.12

Öte yandan Şamlıların da genel olarak kırmızı giymeye karşı olduklarını söyleyebiliriz. ${ }^{13}$ Yukarıdaki rivâyete ilave olarak aşağıda Şamlılara isnâd edilen rivâyetlerde de bu durumu görebilmekteyiz:

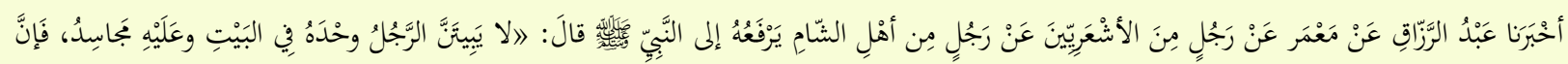

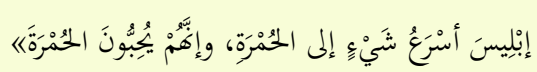

Eş'arîlerden bir adam Şamlılardan bir adamdan, Nebî́ye (s.a.s.) ref' ederek şunu haber vermektedir: "Kişi üzerinde kadın giysileri olduğu halde evinde tek bir gece dahi geçirmesin. Zira iblis kırmızı rengi sevdiğinden, bu renkte olan şeylere çabucak yanaşır." 14

Diğer bir rivâyetleri ise şu şekildedir:

\footnotetext{
${ }^{10}$ Bu hadisi Tâvûs'tan oğlu dışında sadece Mekkeli bir talebesi olan Süleyman el-Ahvel'in rivâyet etmiş (Müslim, "Libâs", 28 (2077) olması da hadisin Mekke menşeli olduğuna dair bir karinedir.

${ }^{11}$ Ma'mer, Câmi', 11: 77 (No. 19965).

12 Tayâlisî, Müsned, 4: 36 (No. 2392); Ahmed, Müsned, 11: 524 (No. 6931); Müslim, “Libâs”, 27 (No. 2077). Söz konusu hadis İsrâîl b. Yûnus (ö. 160/777?) tarafından da nakledilmiş olmakla birlikte (Bk. Ebû Dâvûd, Libâs, 20 (No. 4069) bu rivâyet Ebû Yahyâ el-Kattât ve İsrâîl dolayısıyla zayıf bulunmuştur. Zira Ebû Yahyâ zayıf bir râvi olarak nitelendirilmiş ve Ahmed b. Hanbel, İsrâîl' in ondan rivâyetlerini münker olarak kabul etmiştir (Bk. İbn Hacer, Tehzîb, 6: 172). Nitekim bu tarik dışındaki rivâyetlerin tamamı Şamlılardandır.

${ }^{13}$ Müslim'in Şamlıların Abdullah b Amr rivâyetini asıl olarak zikretmiş olması, ona göre bu konudaki en muteber hadisin bu olduğunu göstermektedir diyebiliriz.

${ }^{14}$ Ma'mer, Câmi', 11: 78 (No. 19969). Yukarıda görüldüğü üzere bu hadisin isnâdında inkıta' söz konusudur.
} 


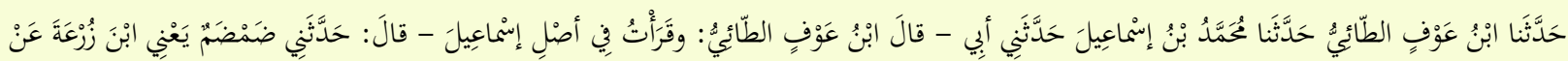

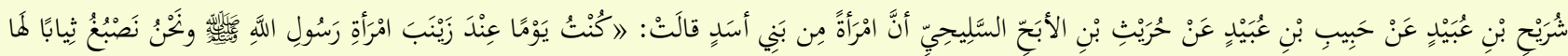

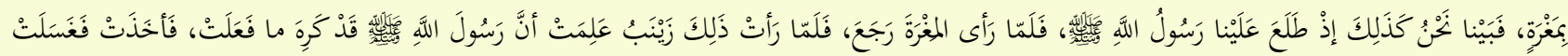

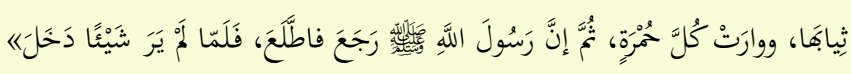

... Esedoğullarından bir kadının şöyle dediği rivâyet edilmiştir: Ben bir gün Rasûlullah’ın (s.a.s.) eşi Zeynep'in yanındaydım. Biz Zeynep'e ait elbiseleri kırmızı ile boyuyorduk. O sırada Rasûlullah (s.a.s.) çıkageldi ve kırmızı kili görünce döndü ve gitti. Zeynep bunu görünce Rasûlullah'ın (s.a.s.) yaptığımız işten hoşlanmadığını anladı. Bunun üzerine elbiselerini aldı ve yıkadı. Onlarda bulunan kırmızılığın tümünü gözden kaybetti. Bir süre sonra Rasûlullah (s.a.s.) tekrar döndü geldi ve baktı. Bir şey (kırmızı boyayı) görmeyince içeri girdi."15

Nitekim Şam’a yerleşen İbn Şihâb ez-Zührî́nin (ö. 124/742) de (kadınlar için değil de) erkekler için kırmızı giymeyi hoş karşılamadığını görmekteyiz. ${ }^{16}$

Bu konuda Mekkeli bazı tefsircilerin tavrı da Şamlılarınkine benzemektedir. Nitekim Mekkeli Mücâhid (ö. 103/721) Kasas suresi 79. ayetindeki "Kârun, ziynetiyle kavminin karşısına çıkardı." "ziynet" kelimesini “kırmızı elbise" şeklinde tefsir etmiştir. ${ }^{17}$ Muhtemelen bu ayetten hareketle Atâ' ve Tâvûs da erkekler için kırmızı giymeyi mekruh görmüşlerdir.18

İbn Abdilber (ö. 463/1071) bu konudaki ihtilafı şu şekilde dile getirmektedir:

Erkeklerin kırmızıya ve sarıya boyanmış elbiseyi giyinmesi hususunda selef ihtilaf etmiştir. Bazıları bunu kerih görürken diğer bazıları bunda bir sakınca bulmamıştır... Erkeklere kırmızı giymeyi mekruh görenlerden bazıları şunlardır: Hasan-1 Basrî, Atâ (b. Ebî Rabâh) (ö. 114/732), Tâvus, Mücâhid ve Zührî. ${ }^{19}$

Kaynaklarda kırmızı giyinmeye karşı çıkanlar arasında Medineli Saîd b. Müseyyeb'in (ö. 94/713) ismi de zikredilmektedir. ${ }^{20}$ Görüldüğ̈̈ üzere kırmızı giyinmeyi mubah görme hususunda Kûfeliler, mekruh görme hususunda ise Şamlılar arasında bir ittifak var gibidir. Diğer şehirlerden ise bu konuda ihtilaflı bazı rivâyetler nakledilmektedir.

Ancak İbn Abdilber'in de belirttiği üzere bu yasak sadece erkelere yönelik kabul edilmiş, kadınlara yönelik bir kerahetten bahsedilmemiştir. ${ }^{21}$ Her ne kadar Ahmed b. Hanbel'in (ö. 241/855)

15 Ebû Dâvûd, "Libâs", 18 (No. 4071). Şuayb el-Arnaût hadisin tahkîkinde isnâdının zayıf olduğunu belirtmektedir.

16 İbn Abdilber, el-ístizkâr, 8: 302.

17 Ahmed, el-Ver', 184. Ayrıca Mücâhid, Abdullah b. Amr'dan nakledilen kırmızı giymenin nehyedilmesi ile ilgili rivâyetin râvilerindendir (Bk. Ebû Dâvûd, "Libâs", 20 (No. 4069)).

18 İbn Ebî Şeybe, Musannef, 5: 159 (No. 24737).

19 İbn Abdilber, el-i̇stizkâr, 8: 300-301.

${ }^{20}$ Abdürrezzâk, Musannef, 7: 41 (No. 12105).

${ }^{21}$ Bunun destekleyen bazı rivâyetler için bk. Ma'mer, Câmi', 11: 76 (No. 19956); İbn Sa'd, Tabakât, 8: 56. 
19 Hüseyin Akgün / Kırmızı Kıyafet Giymenin Hükmü ile İlgili Rivâyetlerin Coğrafî Tahlîli / Geographic Analysis of Hadiths Regarding Prohibition of Wearing Red

bunu kadınlara dahi hoş görmediği nakledilse de 22 Ebû Dâvûd'a (ö. 275/889) göre Ahmed, bunu sadece erkekler için mekruh görmüştür. ${ }^{23}$

Şimdi de kırmızı giymenin neden bazıları tarafından hoş karşılanmamış ve yasaklanmış olabileceği üzerinde durmak istiyoruz.

\section{KIRMIZI GIYMENIN MUHTEMEL YASAKLANMA SEBEPLERI}

Kırmızı giymenin yasaklanması veya çirkin görülmesinin nedenleri ile ilgili farklı rivâyetlere rastlamaktayız. Bunlardan bir kısmı bu rengin kadınlara mahsus bir ziynet olarak görülmesi ile ilgilidir. Basralıların kaynağı meçhul munkatı` bir rivâyetinde Hz. Ömer' in (ö. 23/644) bir adamın kırmızı bir elbise giymesini eleştirerek "Kadınlar için olan şu parlak renkleri (giymeyi) bırakın!" dediği nakledilmektedir. ${ }^{24}$

Kırmızı giymenin kibir alameti olarak görülmesi nedeniyle yasaklandığ1 da düşünülebilir. Nitekim bu renkteki elbiselerden, özellikle “" olarak ifade edilen kırmızı elbisenin Karun'a nispet edilmesi, bunun zenginlerin giydiği özel elbiselerden olabileceğini ihsas etmektedir. Bu bağlamda kırmızının, şöhret ve gösterişi ifade ettiği söylenmektedir. ${ }^{25}$ Nitekim birçok müfessir, onu Karun'un ziyneti olarak nitelendirmiştir. ${ }^{26}$ Dolayısıyla bu mürüvvete uygun görülmemiştir diyebiliriz.

Diğer yandan merfû bir rivâyette kırmızı kıyafetin kâfirlere benzeme kanaatiyle yasaklandığı yukarıda Abdullah b. Amr rivâyetiyle nakledilmişti. ${ }^{27}$

İbn Hacer (ö. 852/1449) de bu konuda üç ihtimalden bahsetmektedir. Birincisi, yasaklamanın kırmızının kâfirlere mahsus bir elbise kabul edilmesidir. ${ }^{28}$ İkinci ihtimal, bunun kadın ziyneti kabul edilmesi, dolayısıyla kadınlara benzemenin yasaklanması ile ilgilidir. Üçüncü ihtimal ise gösterişli, dolayısıyla erdemli insanlara (mürüvvet ehline) yakışmayan bir elbise olmasıdır. ${ }^{29}$

Yukarıda tespit ettiğimiz gerekçelerin dışında, bunun siyasî/mezhebî bir anlamının da olduğunu söyleyebiliriz. Nitekim kırmızı kıyafetler giyerek nebîz içme âdeti, Kûfelilerin ve çoğu Basralıların mezhebi olarak zikredilmiştir. Bunu Iraklılar şu şekilde nakletmektedirler:

22 Ahmed, el-Ver', 184.

${ }^{23}$ Ahmed, Mesâilu Ebî Dâvồd, 350.

${ }^{24}$ Ma'mer, Câmi', 11: 78 (No. 19970); İbn Ebî Şeybe, Musannef, 5: 159 (No. 24735). Ayrıca bunun kadın elbisesi ile ilgili olduğu yönündeki bir vurgu için bk. Ma'mer, Câmi', 11: 78 (No. 19969).

${ }^{25}$ Müerric es-Sedûsî (ö. 195/811) şu sözü nakletmektedir: “ العصفر فخر، والزعفران عطر، والمشق فقر = Kırmızı şöhrettir, za'feran (sarı renkli) hoş kokuludur, yün fakirliktir.” (Sedûsî, el-Emsâl, 80). Ayrıca bk. Taberânî, el-Evsat, 7: 353 (No. 7708).

26 Taberî, Tefsîr, 18: 328; İbn Atıyye, el-Muharrer, 4: 301. Ancak İbn Atıyye (ö. 541/1147) bu haberi sahih kabul etmemiştir. Öte yandan İmam Mâlik de bunun sadece çarşı pazarda giyilmesini uygun görmemekle, onun kırmızı giymeyi mekruh görmesinin illetinin şöhret ve gösteriş olduğunu ihsas etmektedir (Kâdî İyâz, İkmâlu'l-Mu'lim bi fevâidi Müslim, 6: 589).

27 Tayâlisî, Müsned, 4: 36 (No. 2392); Ahmed, Müsned, 11: 524 (No. 6931).

28 İbn Hacer bunu Rasûlullah'ın döneminde daha çok acemlerin kullandığı ve lükse işaret eden kırmızı eyer yastıklarına (الميَّرَة الحَمْراءٍ) benzetmektedir. Ancak bu durumun değiştiğini, artık onlara özgü bir şey olmadığından kerahetten söz edilemeyeceğini belirtmektedir (Bk. İbn Hacer, Feth, 10: 307).

${ }_{29}$ Bk. İbn Hacer, Feth, 10: 306. 


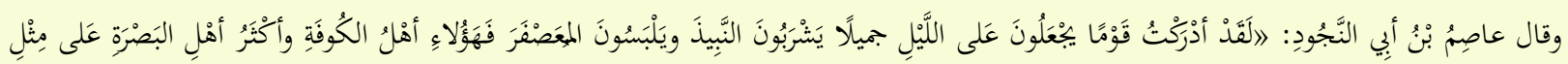

Âsım b. Ebi'n-Necûd (el-Kûfî) (ö. 128/746) dedi ki: “Kırmızı elbise giyip nebîz içerek geceyi güzelleştiren (eğlenen) bir topluluğa rastladım. İşte bunlar Kûfelilerdir. Basralıların çoğu da onların mezhebi üzeredirler." 30

Yukarıdaki rivâyeti destekleyen, aslında kırmızı kıyafetin acem kıyafeti olduğu yönünde -sanki buna itirazı ifade eden- şöyle bir rivâyet de dikkat çekmektedir:

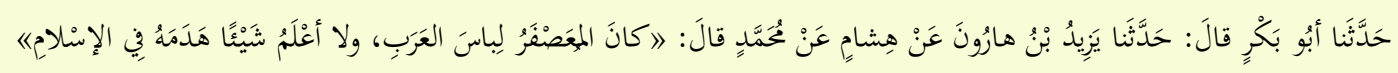

...Muhammed b. Sîrîn (ö. 110/729): “Kırmızı, Arapların elbisesiydi. Ben İslam' da bunu ortadan kaldıran bir şey (hüküm) bilmiyorum." 31

Yine Muhammed el-Bâkır'dan (ö. 114/733) gelen Kûfe menşeli rivâyette de bunun mezhebî/ siyasî bir yönü olabileceğine bir işaret bulunmaktadır:

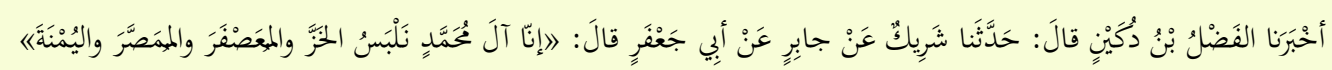

...Ebû Ca'fer (Muhammed el-Bâkır): “Biz ipek, kırmızı, açık kırmızı ve Yemen cübbesi giyen Âli Muhammed'iz. "32

Öte yandan kırmızı (ve sarı) giymenin sadece ihramlıya yasak olan tîb (güzelleşme/süslenme) nedeniyle yasaklandığı yönünde rivâyetlerin bulunduğu da belirtilmelidir. ${ }^{33}$ Bunu tîb saymayanlar ihramlıyken kırmızı elbise de giymişlerdir. ${ }^{34}$ Ancak Mâlik (ö. 179/795) vücut üzerinde dalgalanıp titrediğinden kırmızı giymeyi tîb saymıştır. ${ }^{35}$

\section{KIRMIZI GIYMEYI MUBAH GÖSTEREN RIVÂYETLER VE BU YÖNDEKİ GÖRÜŞLER}

Her ne kadar bu yasağın yalnız erkeklere özgü olduğu ifade edilmiş olsa da bu konuda bizzat Rasûlullah'ın kırmızı elbise giydiği yönünde rivâyetler de bulunmaktadır. Ancak bu rivâyetlerin sadece Kûfeliler tarafından nakledilmiş olması dikkat çekmektedir. Bunlardan biri aşağıdaki rivâyettir.

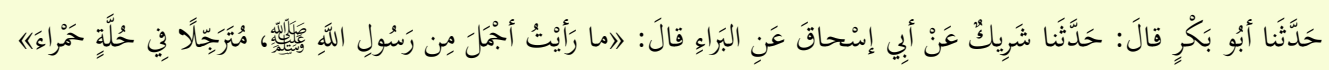

...Berâ b. Âzib (ö. 71/690?): “Rasûlullah (s.a.s.) saçlarını taramış olduğu halde kırmızı bir elbise içinde iken ondan daha güzel hiç kimseyi görmedim." 36

\footnotetext{
30 İbn Kuteybe, Eşribe, 178. Söz konusu haberin diğer rivâyetleri için bk. Kâsım b. Sellâm, Garîbu'l-hadîs, 5: 538; İbn Sa'd, Tabakât, 6: 158; İbn Ebî Şeybe, Musannef, 5: 58 (23938).

31 İbn Ebî Şeybe, Musannef, 5: 158 (No. 24725).

32 İbn Sa'd, Tabakât, 5: 247. Burada 'yasak edilen cart kırmızıdır' gibi bir iddiaya da cevap var gibidir.

33 Tayâlisî, Müsned, 3: 401 (No. 1991).

34 Kâsım b. Sellâm, Garîbu'l-hadîs, 5: 12.

${ }^{35}$ Mâlik'in bu yöndeki kanaati için bk. Irâkî, Tarhu't-tesrîb, 3: 235.

36 İbn Ebî Şeybe, Musannef, 5: 157 (No. 24715). Hadisin diğer bir rivâyeti için bk. Tayâlisî, Müsned, 2: 92 (No. 757$).$
} 
21 Hüseyin Akgün / Kırmızı Kıyafet Giymenin Hükmü ile İlgili Rivâyetlerin Coğrafî Tahlîli / Geographic Analysis of Hadiths Regarding Prohibition of Wearing Red

Rasûllulah'ın kırmızı bir kıyafet giydiği yönünde Berâ b. Âzib dışında Câbir b. Semüre (ö. 76/696) ${ }^{37}$ ve Târık b. Abdullah el-Muhâribî' den ${ }^{38}$ rivâyetler bulunmaktadır. Görüldügüu üzere bunların her üçü de Kûfe'ye yerleşen sahâbîlerdendir. ${ }^{39}$

Kırmızı giyme ile ilgili rivâyetleri toplu olarak görebildiğimiz İbn Ebî Şeybe'nin (ö. 235/849)

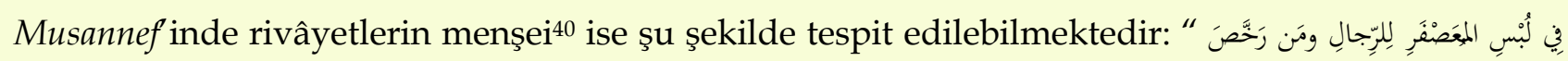
"فِيِ başlığı altında on beş rivâyet bulunmaktadır. Bunlardan dokuzu Kûfeliler, üçü Basralılar, ikisi Medineliler, ${ }^{41}$ biri Vâsıtlılar,42 bir diğeri Horasanlılar"3 tarafından nakledilmektedir. Müteakiben “ مَن

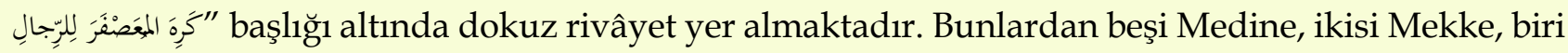
Şamlılar tarafından rivâyet edilmektedir. Rivâyetlerden birinin râvileri ise meçhuldür.

Kütüb-i Sitte içerisinde de benzer bir durumu görebilmekteyiz. Yukarıda geçtiği üzere Buhârî (ö. 256/870), sadece kırmızı giymenin mubahlığı yönündeki Kûfe menşeli iki hadisi sahih bularak eserinde tahric etmektedir. ${ }^{4}$ Buna karşılık bunun kerâhiyeti ile ilgili hiçbir hadise yer vermemektedir. Müslim'e (ö. 261/875) gelecek olursak Buhârî́den farklı olarak o, gerek lehte gerekse aleyhte ${ }^{45}$ olan hadisleri kitabının muhtelif yerlerinde tahric etmiştir. Bununla birlikte lehte

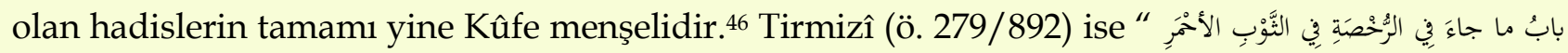
"لِِلِِجالِ başlığı altında tek bir hadis rivâyet etmektedir ki o da Kûfeliler tarafından Berâ b. Âzib'den nakledilmektedir. Buna karş1lık " başl1ğ1 altında naklettiği tek hadis ise

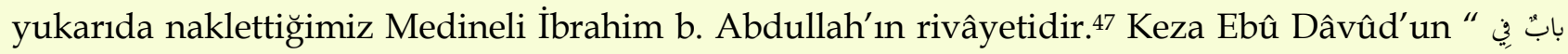

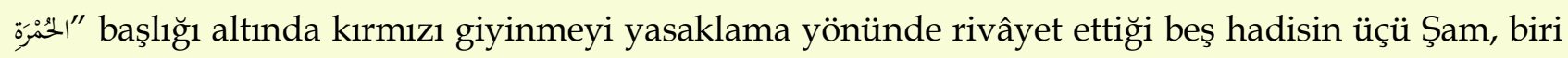

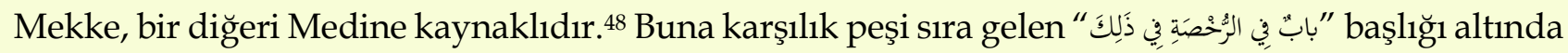

37 Tirmizî, “Edeb”, 47 (No. 2811).

38 Begavî, Mu'cemü's-sahâbe, 3: 426.

${ }^{39}$ Akgün, Hadis Rivâyet Coğrafyası, 95-96. Târık b. Abdullah için bk. Zehebî, Târihu'l-İslâm, 2: 507.

$40 \quad$ Hadislerin menşeini tespitte ilk iki, üç râvi dikkate alınmıştır. Bu da en geç hadislerin yaygın olarak rivâyet edilmeye başladığı yaklaşık 150'li yıllara tekabül etmektedir. Bk. Akgün, Hadis Rivâyet Coğrafyası, 18, 191.

${ }^{41}$ Bunlardan ilki Nâfi' b. Cübeyr'in kırmızı giydiği ilgili rivâyettir (İbn Ebî Şeybe, Musannef, 5: 157 (No. 24716), ki bunu sadece Basralı İbn Uleyye, yine Basra'ya gelmiş olan ve cerh edilmiş bir râvi olan Abdurrahman b. İshak'tan nakletmektedir (Râvi için bk. Mizzî, Tehzîbu'l-Kemâl, 16: 519-525). İkincisi ise Hişâm'in rivâyetidir (İbn Ebî Şeybe, Musannef, 5: 158 (No. 24726) ki, ondan bunu sadece Kûfeli bir râvi olan Ebû Muâviye nakletmektedir. Hişâm'dan ise Kûfelilerin rivâyeti muteber kabul edilmemiştir (İbn Receb, Şerh, 2: 769).

${ }^{42}$ Irak'ta bugün mevcut olamayan bir şehirdir. Kûfe ile Basra arasında bulunan Vâsıt Bağdat'a $180 \mathrm{~km}$ uzaklıktadır. Bk. Mehmet Mahfuz Söylemez, "Vâsıt", 42: 541.

${ }^{43}$ Horasan'ın rivâyet konusunda Irak'ın etkisi altında olduğu bilinmektedir. Bk. Akgün, Hadis Rivâyet Coğrafyası, 179.

${ }^{44}$ Birincisi için bk. Buhârî, "Salât", 17 (No. 376). İkincisi için bk. Buhârî, "Libâs”, 35 (No. 5848).

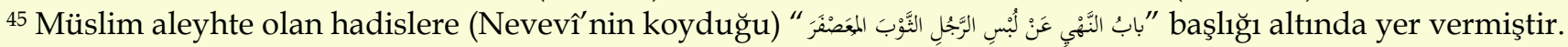
Sırasıyla bunlar Şam, Mekke ve Medinelilere ait rivâyetlerdir.

${ }^{46}$ Müslim, "Salât", 249, 250 (No. 503); "Fezâil", 91,92 (No. 2337).

47 Tirmizî, "Libâs", 4 (No. 1724), 5 (No. 1725).

${ }^{48}$ Ebû Dâvûd, "Libâs", 20 (No. 4066-4071), 21 (No. 4072-4073). Sünen'in tahkikinde Şuayb el-Arnaût (ö. 2016) bunlardan birincisine hasen, ikincisine sahih hükmünü vermekle birlikte kalan dördüne zayıf demektedir. 
ise $\mathrm{o}$, iki merfû hadise yer vermektedir ki bunların her ikisi de Kûfe kaynaklı olarak nakledilmektedir.49 İbn Mâce'de (ö. 273/887) “بابُ لُبسِ الأحمَمِ لِلرِّجالِ başlığ1 altında ilki Kûfelilerden,

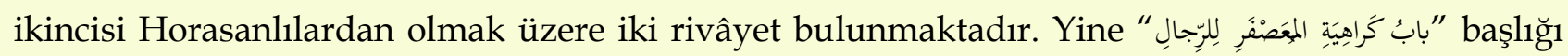
altındaki hadislerin ikisi Medinelilerden, biri ise Şamlıların Mekkeli Amr b. Subayb'dan (ö. 118/736)

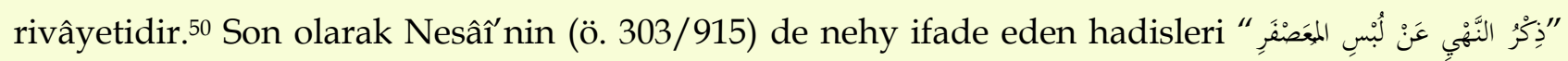
başlığı altında topladığını görmekteyiz. Bunlar Müslim'deki ve Ebû Dâvûd'daki aynı sırayla ilki Şamlıların, ikincisi Mekkelilerin, üçüncüsü ise Medinelilerin rivâyetidir. Kırmızı giyinmenin mubahlığı ise kitabın muhtelif yerlerinde yine sadece Kûfeliler tarafından nakledilmektedir. ${ }^{51}$

Bütün bunlar kırmızı giymeye ruhsat veren haberlerin tamamına yakınının Kûfe ve Basra yani Irak menşeli, buna karşılık yasaklayan rivâyetlerin ise Şam, Mekke ve Medine kaynaklı olduğunu göstermektedir.52

Öte yandan Kûfelilerden gelen Hz. Ali rivâyetlerinde ise Hz. Peygamber'in kırmızı kıyafet giymeyi değil, kırmızı eyeri yasakladığ1 görülmektedir. ${ }^{53}$ Hatta Ebû Ubeyd Kâsım b. Sellâm (ö. 224/838) bu eyerlerin menşeinin Acemler olduğunu ve bunların ipekten yapıldığını bildirmektedir. ${ }^{54}$ Keza Basralılardan gelen rivâyetlerde de bu kırmızı eyer kullanmaya muhalefeti görmekteyiz. 55

İsim bazında araştırdığımızda Kûfelilerden Şa'bî (ö. 104/722),,56 İbrahim en-Nehâ̂, ${ }^{57}$ Hammâd b. Ebî Süleyman' in (ö. 120/738)58; Basralılardan ise Enes b. Mâlik (ö. 93/712), ${ }^{59}$ İbn Sîrîn60, Ebû Miclez (ö. 106/724) ${ }^{61}$ ve İbrahim et-Teymî́nin (ö. 92/711) kırmızı giydikleri bildirilmektedir. ${ }^{62}$

Burada bazı Medineli sayılabilecek sahâbî ve tâbiînden de kırmızı giydiği belirtilen kişiler dikkat çekmektedir: Hz. Ali,63 Talha b. Ubeydullah,64 Saîd b. Müseyyeb,65 Urve b. Zübeyr (ö.

49 Şuayb el-Arnaût eserin tahkîkinde her iki rivâyet için sahih hükmünü vermektedir. Bu rivâyetlerden ikincisinde Hz. Ali'nin de Rasûlullah'ın kırmızı bürde giydiğine şahit olduğunun belirtilmesi dikkat çekmektedir.

50 İbn Mâce, "Libâs", 20 (No. 3599-3603).

51 Nesâî, "Kıble”, 21 (No. 772); "Zînet”, 9 (No. 5060). Rivâyetlerin isnâdlarına bakıldığında ise, kırmızı giymeyi mubah sayan hadislerin daha güvenilir olduğu, buna karşılık Müslim'de geçen Abdullah b. Amr rivayeti hariç kırmızı giymeyi yasaklayan hadislerin illetli olduğu da görülmektedir.

${ }^{52}$ Benzer şekilde yine tamamı Iraklılar tarafından nakledilen rivâyetlerde diğer sarı giyinmek de caiz görülmektedir. Bk. İbn Sa'd, Tabakât, 1: 350; İbn Ebî Şeybe, Musannef, 5: 160 (No. 24749-24752).

${ }^{53}$ Bk. Abdürrezzâk, Musannef, 2: 144 (No. 2836); Ebû Dâvûd, “Libâs", 11 (No. 4051).

${ }^{54}$ Kâsım b. Sellâm, Garîbu'l-hadîs, 1: 285.

55 Bk. İbn Ebî Şeybe, Musannef, 5: 202 (No. 25235-25237).

${ }^{56}$ Ebû Yusuf, el-Âsâr, 234; İbn Sa'd, Tabakât, 6: 264.

${ }^{57}$ Ebû Yusuf, el-Âsâr, 231.

58 İbn Sa'd, Tabakât, 6: 324.

59 İbn Sa'd, Tabakât, 7: 17.

60 İbn Ebî Şeybe, Musannef, 5: 158 (No. 24721).

61 İbn Maîn, Târîhu İbn Maîn (rivâyetu ed-Dûrî), 4: 293.

62 İbn Ebî Şeybe, Musannef, 5: 157 (No. 24717).

${ }^{63}$ Muhammed b. Abdullah el-Ensârî, Hadîsu Muhammed b. Abdullah el-Ensârî, 37.

64 İbn Sa'd, Tabakât, 3: 164.

65 İbn Sa'd, Tabakât, 5: 105. Basralıların bu rivâyetinden farklı olarak, yukarıda İbn Müseyyeb'in kırmızı giymeyi reddeden, Şam'a yerleşen Atâ el-Horasânî́nin (ö. 135/752) kendisinden bir rivâyeti bulunduğu da burada 
23 Hüseyin Akgün / Kırmızı Kıyafet Giymenin Hükmü ile İlgili Rivâyetlerin Coğrafî Tahlîli / Geographic Analysis of Hadiths Regarding Prohibition of Wearing Red

94/713) ${ }^{66}$ ve Nâfi' b. Cübeyr ${ }^{67}$ gibi. Ancak bu yöndeki bilgiler de büyük oranda Iraklılar tarafından nakledilmiştir.

Diğger yandan yukarıda ifade edildiği üzere Ebû Ca'fer Muhammed el-Bâkır'dan Ehl-i beytin de kırmızı giydiği rivâyeti gelmiştir.

Son olarak mezheplerin kırmızı giyme konusundaki görüşlerine de yer vermek istiyoruz. Ebû Hanîfe (ö. 150/767) kırmızı giymeyi caiz görenlerdendi. ${ }^{68}$ Mâlik, bunun haramlığı konusunda bir şey bilmediğini, ancak kırmızı giymeyi tercih etmediğini ifade etmektedir. ${ }^{99}$ Şâfiî (ö. 204/820) ise kırmızı giymeyi mubah görmekte ve bunu nehyeden bir hadisin olmadığını savunmaktadır. O, Hz. Ali' den gelen rivâyet "Rasûlullah beni nehyetti (diyorum), sizi nehyetti demiyorum" şeklinde olduğu için bunu sadece ona mahsus bir durum olarak görmüştür. Beyhakî (ö. 458/1066) ise bu konuda başka hadisler olduğunu savunarak ona itiraz etmektedir. ${ }^{70}$ Ancak görüldüğü üzere Şâfiî de hocası Mâlik gibi bu rivâyetlerden bihaberdir.

Öte yandan İbn Abdilber, kırmızı giyen ve bunda bir sakınca görmeyenler arasında; Abdullah b. Ömer (ö. 73/693), Berâ b. Âzib (ö. 71/690?), Talha b. Ubeydullah (ö. 36/656), Ebû Ca'fer Muhammed b. Ali (el-Bâkır) (ö. 114/733), İbrahim en-Nehâî (ö. 96/714), Muhammed b. Sîrîn (ö. 110/729), Ebû Vâil Şakîk b. Seleme (ö. 82/701), Zir b. Hubeyş (ö. 82/701), Ali b. Hüseyin (ö. 94/712) ve Nâfi' b. Cübeyr b. Mut'im (ö. 99/717) isimlerini vermektedir. Ayrıca yukarıda ifade edildiği üzere Ebû Hanîfe, Mâlik ve Şâfiî de bu isimler arasındadır. ${ }^{71}$ Keza İbn Abdilber'e göre Medinelilerin çoğu kırmızı giymeye ruhsat vermişlerdir. ${ }^{72}$ Yine İbn Abdilber' in tespitine göre mekruh görenler ise şu âlimlerdir: Hasan-1 Basrî, Atâ, Tâvûs, Mücâhid ve Zührî.73

Renklerin devlet ve topluluklar için her zaman bir sembolik ve temsili değeri olmuştur. ${ }^{74}$ İslam toplumunda da tarih boyunca bu durum tespit edilebilmektedir. Abbasîler daha sonra da Selçuklular gibi bazı devletlerin siyah bayrak kullanmaları buna örnek verilebilir. ${ }^{75}$ Renklerin bu temsil dilini toplum içindeki sınıflarda da görebilmekteyiz. Öyle ki Memluklerde zimmîler mensup oldukları dine göre değişik renklerde; Hristiyanlar mavi, Yahudiler sarı ve Sâmirîler kırmızı sarık

hatırlanmalıdır (Bk. Abdürrezzâk, Musannef, 7: 41 (No. 12105). Dolayısıyla her iki cenahın kendi uygulamalarını destekleyen bu rivâyetin ancak biri doğru olabilir.

66 İbn Ebî Şeybe, Musannef, 5: 158 (No. 24726).

67 İbn Ebî Şeybe, Musannef, 5: 157 (No. 24716).

${ }^{68}$ Irâkî, Tarhu't-tesrîb, 3: 235.

${ }^{69}$ Mâlik, "Libâs", 4. Kâdî İyâz'a (ö. 544/1149) göre, Mâlik şöhret için çarşı pazarda giymeyi mekruh kabul etmiştir (Kâdî İyâz, İkmâlu'l-Mu'lim bi fevâidi Müslim, 6: 589).

${ }^{70}$ Nevevî, Şerhu'n-Nevevî alâ Müslim, 14: 54.

${ }^{71}$ Bk. İbn Abdilber, el-İstizkâr, 8: 300.

72 Bk. İbn Abdilber, el-İstizkâr, 8: 302.

${ }^{73}$ Bk. İbn Abdilber, el-İstizkâr, 8: 301.

${ }^{74}$ Bu konuda bk. Fuat Yöndemli, “Değişik İnanç, Kültür ve Dinlerde Renklerin Anlam ve Önemi”, Müjgân Üçer'e Armağan, İstanbul: Kitabevi, 2011, 410-421.

75 Bk. Orhan F. Köprülü, "Bayrak", 5: 249-253. Siyahın Abbasîlerin şiarı olduğu hususunda bk. Azze Huseyn Gurâb, "el-Elvân ve delâletühâ's-siyâseti fi'l-asri'l-Abbâsî", el-Mecelletü'l-ilmiyye bi külliyeti'l-âdâb, 19 (2006), 49. 
sararlard1. ${ }^{76}$ Yine dinî bir sembol olarak Muhammire fırkası mensupları elbiselerini kırmızıya boyard1. ${ }^{77}$ Keza Aleviler için de kırmızı rengin önemli bir sembol değeri vardır. ${ }^{78}$

Araştırmamızdan ulaştığımız sonuca göre kırmızı kıyafetin Iraklılar (özellikle Kûfeliler) için de sembolik bir değerinin olduğunu söyleyebiliriz. Buna karşılık söz konusu renge muhalefet konusundaki rivâyetlerde onların siyasî rakipleri olan Şamlıların çok sayıdaki yasaklayıcı rivâyetleri ile diğer bölgelere göre öne çıktığı da dikkat çekmektedir. Nitekim daha sonra siyah rengi benimseyen Abbasîlere isyanın rengi de kırmızı olmuştur.79 Ancak kırmızı giymenin keraheti, yukarıda da ifade edildiği üzere sadece siyasî bir sebebe bağlamak yanlış olur. Bu kerahet iddiasını besleyen ve sonradan ortaya çıkan, kâfirlere benzememe, kadın giysisi veya ziynet olarak görülmesi gibi dinî ve kültürel bir yönünün olabileceği de inkâr edilemez.

Bütün bunlar bir yana bizim asıl dikkat çekmek istediğimiz husus ister dinî olsun ister siyasî, bir bölge halkının herhangi bir konudaki tutumunun rivâyetlerin menşeine yansımasıdır. Ancak bölgesellikten her zaman hadislerin söz konusu bölgede uydurulduğu manası çıkarılmamalıdır. ${ }^{80}$ Bazen bu algıda seçicilik ve tercihin bir yansıması olarak bir konuda gelen birbiriyle çelişen haberlerden her bölgenin kendi tezlerini destekleyen haberleri öne çıkarması, muhalif olan haberleri ise ihmal etmesi sonucu tabî olarak böyle bir tablonun ortaya çıkmasına da neden olabilmiştir.

\section{SONUÇ}

Tarihte ve günümüzde kırmızı giymeyi hoş karşılamayan Müslümanlar var olmuştur. Bunun kaynağını araştırdığımızda Hz. Peygamber'e, sahâbe ve tâbiîne dayanan kırmızı giymenin yasaklanması veya keraheti ile ilgili çok sayıda rivâyete rastlamaktayız. Bu rivâyetlerin önemli bir kısmı kırmızı kıyafet giymeyi yasaklarken, diğer bir kısmı ise bunun mubahlığını ifade etmektedir.

Hz. Ali'den Medineli İbrahim b. Abdullah b. Huneyn aracılığıla nakledilen ve kırmızı elbise giymenin yasaklandığı hadisin Kûfe varyantlarında bu yasağın yer almaması dikkat çekicidir. Kûfelilerin rivâyetlerinde kırmızı kıyafet yerine, kırmızı eyer kullanmanın yasaklanması ziyadesi bulunmaktadır. Dolayısıyla Kûfelilerin bu hadisin zabtı konusunda Medineli İbrahim'e muhalefet etmişlerdir.

Rivâyetlerin hadis rivâyet coğrafyası bakımından menşeini araştırmamız neticesinde bu kırmızıya muhalefetin Şam, Mekke ve bazı Medinelilerin rivâyetlerinde yer aldı̆̆ını tespit ettik. Ancak Basralılardan gelen kırmızı giymeyi nehyedici rivâyetlerin tamamının kaynak tarafının munkatı' olduğunu, dolayısıyla -en azından hicrî ilk yüzyılda- kendilerine isnâdının şüpheli olduğunu düşünmekteyiz. Nitekim Basralılardan Enes b. Mâlik, İbn Sîrîn, Ebû Miclez ve İbrahim et-Teymî́nin kırmızı giydikleri bildirilmektedir. Buna karşılık kırmızı kıyafet giymeyi mubah gören rivâyetlerin tamamının Iraklılar, özellikle Kûfeliler tarafından nakledildiğine şahit olmaktayız.

\footnotetext{
76 Nebi Bozkurt, “Kiyafet”, 25: 509.

77 Mustafa Öz, "Gâliyye”, 13: 336. Muhammire, dinî bir sembol olarak kırmızı elbise giyen ve değişik bölgelerde farklı isimlerle anılan aşırı fırka.

78 Bk. İlyas Üzüm," Kızılbaş", 25: 547, 555.

${ }^{79}$ Gurâb, "el-Elvân ve delâletühâ's-siyâseti fi'l-asri'l-Abbâsî", 74.

80 Bölgeselliği nedenleri konusunda bk. Akgün, Hadis Rivâyet Coğrafyası, 97 vd.
} 
25 Hüseyin Akgün / Kırmızı Kıyafet Giymenin Hükmü ile İlgili Rivâyetlerin Coğrafî Tahlîli / Geographic Analysis of Hadiths Regarding Prohibition of Wearing Red

$\mathrm{Bu}$ muhalefetin altında ne olabilir sorusuna cevap mahallinde, İbn Hacer el-Askalânî bu yasaklamayla ilgili üç ihtimalden bahsetmektedir. Birincisi kırmızının kâfirlere mahsus bir elbise kabul edilmesidir. İkinci ihtimal ise bunun kadın ziyneti kabul edilmesi, dolayısıyla kadınlara benzemenin yasaklanması ile ilgilidir. Üçüncü ihtimal ise gösterişli, dolayısıyla erdemli insanlara yakışmayan bir elbise olmasıdır. Biz ise bu gerekçeler dışında yasak ifadelerinin daha çok siyasî/mezhebî bir anlamının olduğunu düşünmekteyiz. Dolayısıyla genel olarak kırmızı giymeyi destekleyen Iraklılar için bu rengin sembolik anlam taşıdığını söyleyebiliriz. Nitekim kırmızı giymenin Iraklıların bir alameti olan nebîz içme ile birlikte zikredilmesi ve diğer bazı Kûfe menşeli rivâyetlerin bu durumu desteklemesi de bunu göstermektedir diyebiliriz.

Yukarıdaki değerlendirmelerimizin söz konusu tartışmaların yoğunlaştığını düşündüğümüz hicrî 1. yüzyılın ortalarından, hicrî 2. yüzyılın ortalarına kadarki dönemle ilgili olduğunu belirtmeliyiz. Zira zamanla topluluklarda bu renk tercihlerinin değişebileceği dikkatten kaçırılmamalıdır.

Sonuç olarak ister dinî ister siyasî olsun, bir bölge halkının herhangi bir konudaki tutumu rivâyetlerin menşeine yansımaktadır. Ancak bölgesellik her zaman hadislerin söz konusu bölgede uydurulduğu manasına gelmemektedir. Bir konuda gelen ve birbiriyle çelişen haberlerden her bölgenin kendi tezlerini destekleyen haberleri öne çıkarması, muhalif olan haberleri ise ihmal etmesi mümkün olabilmektedir. Dolayısıyla hadislerin rivâyet edildiği coğrafyanın dikkate alınarak değerlendirilmesi; bunların sıhhatinin tespiti, mevzû olanların siyasî ve sosyo-kültürel arka planlarının belirlenmesi, bir konudaki hadis metinlerinin yeniden inşası gibi konularda yardımcı olabilmektedir. 


\section{KAYNAKÇA}

Abdürrezzâk, Ebû Bekr Abdürrezzâk b. Hemmâm es-San'ânî. el-Musannef. thk. Habîburrahmân elA'zamî. Beyrut: el-Mektebetü'l-İslâmî, 1983.

Ahmed b. Hanbel. Ebû Abdillâh Ahmed b. Muhammed eş-Şeybânî. el-Müsned. thk. Şuayb el-Arnaût vdğr. Beyrut: Müessesetü'r-Risâle, 2001.

Ahmed b. Hanbel. Kitâbü'l-Vera'. thk. Zeyneb İbrâhim Kârût. Beyrut: Dârü'l-Kütübi'l-İlmiyye, 1983. Akgün, Hüseyin. Hadis Rivâyet Coğrafyası. İstanbul: İFAV, 2019.

Akyüz, Hüseyin. "Hz. Peygamber'in Hadislerinde Renklerin Dili”. Atatürk Üniversitesi İlahiyat Fakültesi Dergisi, 41 (2014), 373-397.

Ali b. Hucr, Ebu'l-Hasen es-Sa'dî. Hadîsu Alî b. Hucr es-Sa'dî an İsmấ'̂́l b. Ca'fer el-Medenî. thk. Ömer b. Refûd b. Refîd es-Süfyânî. Riyad: Mektebetü'r-Rüşd, 1998.

Begavî, Ebu'l-Kâsım Abdullah b. Muhammed. Mu'cemu's-sahâbe. thk. Muhammedu'l-Emîn Muhammed el-Cekenî. Kuveyt: Mektebetu Dâru'l-Beyân, 2000.

Bozkurt, Nebi. "Kiyafet". Türkiye Diyanet Vakfi İslam Ansiklopedisi. 25: 508-510. Ankara: TDV Yayınları, 2002.

Buhârî, Ebû Abdullah Muhammed b. İsmail. el-Câmiu's-Sahîh. thk. Muhammed Züheyr b. Nâsır enNâsır. 9 cilt. Beyrut: Dâru Tavki'n-Necât, 2001.

Dârekutnî, Ebu'l-Hasen Ali b. Ömer. el-İlelü'l-vâride fíl-ehâdîsi'n-Nebeviyye. thk. Mahfûzu'r-rahmân Zeynullah. Riyad: Dâru Taybe, 1985.

Ebû Dâvûd, Süleyman b. Eş'as es-Sicistânî. Mesâilu'l-imâm Ahmed rivâyetu Ebî Dâvûd es-Sicistânî. thk. Eû Muâz Târık b. Avdullah b. Muhammed. Kahire: Mektebetü İbn Teymiyye, 1420/1999.

Ebû Dâvûd, Süleyman b. Eş'as es-Sicistânî. es-Sünen. thk. Şuayb el-Arnaût ve Muhammed Kâmil Karabelli. 7 cilt. Dımaşk: el-Mektebetü’l-Asriyye, 2009.

Ebû Yûsuf, Ya'kûb b. İbrahim el-Ensârî. Kitâbü'l-âsâr. thk. Ebû'l-Vefâ el-Efgânî, Beyrut: Dâru'lKütübi'l-ìlmiyye, ts.

Gurâb, Azze Huseyn. “el-Elvân ve delâletühâ's-siyâseti fi'l-asri'l-Abbâsî”. el-Mecelletü'l-ilmiyye bi külliyeti'l-âdâb. 19 (2006), 37-77.

Halîl b. Ahmed, Ebû Abdurrahmân. Kitâbu'l-Ayn. thk. Mehdî el-Mahzûmî ve İbrahim es-Sâmerâî, Beyrut: Dâru ve Mektebetü'l-Hilâl, ts.

Irâkî, Ebu'l-Fadl Zeynüddîn Abdürrahim b. Huseyn. Tarhu't-tesrîb fî şerhi't-Takrib. Beyrut: Dâru İhyâi't-Türâsi'l-Arabî, ts.

İbn Atıyye, Ebû Muhammed Abdülhak b. Gâlib el-Endelüsî, el-Muharrerü'l-vecîz fì tefsîri'l-kitâbi'lazîz. thk. Abdüsselâm Abduşşâfî Muhammed. Beyrut: Dârü'l-Kütübi'l-İlmiyye, 1422/2001.

İbn Abdilber, Ebû Ömer Yûsuf b. Abdullah. el-İstizkâr. thk. Sâlim Muhammed Atâ ve Sâlim Muhammed Muavvad. Beyrut: Dâru'l-Kütübi'l-İlmiyye, 2000. 
27 Hüseyin Akgün / Kırmızı Kıyafet Giymenin Hükmü ile İlgili Rivâyetlerin Coğrafî Tahlîli / Geographic Analysis of Hadiths Regarding Prohibition of Wearing Red

İbn Ebî Şeybe, Abdullah b. Muhammed. el-Musannef. thk. Kemal Yûsuf el-Hût. Riyad: Mektebetü'rRüşd, 1988.

İbn Hacer, Ahmed b. Ali el-Askalânî. Fethü'l-Bârî şerhu Sahîhi'l-Buhârî. thk. Muhibbuddîn el-Hatîb vdğr. Beyrut: Dâru'l-Ma'rife, 1959.

İbn Hacer, Ahmed b. Ali el-Askalânî. Hedyü's-sârî mukaddimetu Fethi'l-Bârî bi-şerhi Sahîhi'l-Buhârî. thk. Muhibbüddin el-Hatîb. Beyrut: Dârü'l-Ma'rife, 1959.

İbn Hacer, Ahmed b. Ali el-Askalânî. Tehzîbü't-tehzîb. Beyrut: Dâru'l-Fikr, 1984.

İbn Kuteybe, Ebû Muhammed Abdullah b. Müslim b. Kuteybe Dîneverî. Kitâbü'l-eşribe ve ihtilâfi'nnâs fihâ. thk. Yasin Muhammed Sevvâs. Kahire: Mektebetü Zehrâi'ş-Şark, ts.

İbn Mâce. es-Sünen. thk. Şuayb el-Arnaût ve Muhammed Kâmil Karabelli vdğr. Beyrut: Dâru'rRisâleti'l-Âlemiyye, 2009.

İbn Receb, Ebu'l-Ferec Zeynüddîn Abdurrahman b. Ahmed. Şerhu İleli't-Tirmizî. thk. Hemmâm Abdurrahim Saîd. Zerkâ: Mektebetü'1-Menâr, 1987.

İbn Sa'd, Ebû Abdillâh Muhammed b. Sa'd el-Bağdâdî. et-Tabakâtü'l-kübrâ. thk. Muhammed Abdülkâdir Atâ. Beyrut: Dâru'l-Kütübi'l-i̇lmiyye, 1990.

İbn Sîde, Ebu'l-Hasen Ali b. İsmail el-Mürsî. el-Muhassas. thk. Halil İbrahim Ceffâl. Beyrut: Dâru İhyâi't-Türâsi'l-Arabî, 1996.

Kâdî İyâz, Ebu'l-Fazl İyâz b. Musa el-Yahsûbî. İkmâlü'l-Mu'lim bi fevâidi Müslim. 8 cilt. thk. Yahyâ İsmail. Mansûre: Dârü'l-Vefâ, 1419/1998.

Kahraman, Abdullah. “Tâvûs b. Keysân”. Türkiye Diyanet Vakfi İslam Ansiklopedisi. 40: 185-186. İstanbul: TDV Yayınları, 2011.

Kâsım b. Sellâm, el-Herevî Ebû Ubeyd. Kitâbu garîbi'l-hadîs. 5 cilt. thk. Huseyn Muhammed Muhammed Şeref. Kahire: el-Heyetü'1-Âmme lişuuni'l-Metâbi'l-Emîriyye, 1404/1984.

Köprülü, Orhan F. “Bayrak”. Türkiye Diyanet Vakfı İslam Ansiklopedisi. 5: 247-254. İstanbul: TDV Yayınları, 1992.

Ma'mer b. Râşid el-Ezdî. el-Câmi'. nşr. Habîburrahmân el-A'zamî. Beyrut: el-Mektebü'l-İslâmî, 1983.

Mâlik, Ebû Abdillâh Mâlik b. Enes el-Asbahî. el-Muvațța'. nşr. Muhammed Fuâd Abdülbâkî. Beyrut: Dâru İhyâi't-Türâsi'l-Arabî, 1985.

Mâlik, Ebû Abdillâh Mâlik b. Enes el-Asbahî. el-Muvațta': rivâyetu Ebî Mus'ab ez-Zührî el-Merînî. thk. Beşşâr Avvâd Ma'rûf ve Mahmûd Muhammed Halil, Beyrut: Müessesetü'r-Risâle, 1992/1412.

Mizzî, Ebu'l-Haccâc Yusuf b. Abdurrahman. Tehzîbü'l-Kemâl fî esmâi'r-ricâl. Beyrut: Müessesetü'rRisâle, 1980.

Muhammed b. Abdullah el-Ensârî, Ebû Abdullah el-Basrî. Hadîsu Muhammed b. Abdullah el-Ensârî. thk. Mis'ad b. Abdulhamîd Muhammed es-Sa' denî. Riyad: Advâü's-Selef, 1418/1998. 
Müslim, Ebu'l-Huseyn Müslim b. el-Haccâc en-Nisâbûrî. Sahîhu Müslim. Thk. Muhammed Fuâd Abdülbâkî. 5 cilt, Kahire: Dâru İhyâi't-Türâsi'l-Arabî, 1955-1956.

Nesâî, Ebû Abdurrahman Ahmed b. Şuayb. es-Sünenü'l-kübrâ. thk. Hasan Abdülmün'im Şelebî. 12 cilt. Beyrut: Müessesetü'r-Risâle, 2001.

Öz, Mustafa. "Gâliyye”. Türkiye Diyanet Vakfi İslam Ansiklopedisi. 41: 333-337. İstanbul: TDV Yayınları, 1996.

Sedûsî, Ebû Feyd Müerric b. Amr b. Haris Müerric, Kitâbü'l-emsâl. thk. Ramazan Abdü't-tevvâb. Beyrut: el-Hey'etü'l-Misriyyeti'1-Âmme, 1391/1970.

Söylemez, Mehmet Mahfuz. "Vâsıt". Türkiye Diyanet Vakfi İslam Ansiklopedisi. 42: 541-544. İstanbul: TDV Yayınları, 2012.

Taberânî, Ebu'l-Kâsım Süleymân b. Ahmed. el-Mu'cemü'l-evsat. nşr. Târık b. Avdullah b. Muhammed ve Abdülmuhsin b. İbrahim el-Hüseynî. Kahire: Dâru'l-Haremeyn, 1415/1995.

Taberî, Ebû Ca'fer Muhammed b. Cerîr. Târîhu't-Taberî (Târîhu'r-rusul ve'l-mulûk). thk. Muhammed Ebu'1-Fadl İbrahim.Kahire: Dâru'1-Meârif, 1387/1967.

Tayâlisî, Süleyman b. Dâvûd. Müsnedü Ebî Dâvûd et-Tayâlisî. thk. Muhammed b. Abdülmuhsin etTürkî. Kahire: Dâru Hicr, 1999.

Tirmizî, Ebû İsa Muhammed b. İsa. Sünenü't-Tirmizî. thk. Ahmed Muhammed Şâkir v.dğr. 5 cilt. Kahire: Mektebetü ve Matbaati Mustafa el-Bâbî el-Halebî, 1975.

Üzüm, İlyas. "Kızılbaş". Türkiye Diyanet Vakfı İslam Ansiklopedisi. 25: 546-557. Ankara: TDV Yayınları, 2002.

Yahyâ b. Maîn, Ebû Zekeriyyâ Yahyâ b. Maîn el-Bağdâdî. Yahyâ b. Maîn ve kitâbuhü't-Târîh (Rivâyetu'd-Dûrî). thk. Ahmed Muhammed Nurseyf, Mekke: Merkezü'l-Bahsi'l-İlmî ve İhyâi'tTürâsi'l-İslâmî, 1979.

Yöndemli, Fuat. “Değişik İnanç, Kültür ve Dinlerde Renklerin Anlam ve Önemi”. Müjgân Üçer'e Armağan. İstanbul: Kitabevi, 2011, 410-421.

Zebîdî, Ebu'l-Feyz Murtaza Muhammed b. Muhammed. Tâcu'l-arûs min cevâhiri'l-Kâmûs. thk. Ali Şîrî. Beyrut: Dâru'l-Fikr, 1414/1994. 